\title{
Prevalensi Gangguan Elektrolit Serum pada Pasien Diare dengan Dehidrasi Usia Kurang dari 5 Tahun di RSUP Dr. Sardjito Tahun 2013- 2016
}

Rosyida Avicennianing Tyas, ${ }^{*}$ Wahyu Damayanti, ${ }^{* *}$ Eggi Arguni ${ }^{* *}$

"Program Sarjana Fakultas Kedokteran Kesehatan Masyarakat dan Keperawatan, ${ }^{* *}$ Departemen Ilmu Kesehatan Anak Fakultas Kedokteran Kesehatan Masyarakat dan Keperawatan Universitas Gadjah Mada/RSUP Dr. Sardjito, Yogyakarta

Latar belakang. Hingga saat ini, diare masih menjadi salah satu masalah kesehatan dunia, terutama di negara berkembang, termasuk di Indonesia. Salah satu komplikasi lanjutan dari dehidrasi pada diare adalah gangguan elektrolit serum.

Tujuan. Untuk mengetahui prevalensi gangguan elektrolit serum pada pasien diare dengan dehidrasi serta karakteristik klinis pasien dan hubungan antara derajat dehidrasi terhadap gangguan elektrolit serum.

Metode. Penelitian retrospektif dengan rancangan cross sectional menggunakan data rekam medis. Perbedaan dianalisis menggunakan uji Chi-square.

Hasil. Jumlah pasien yang memenuhi kriteria adalah 173 pasien, 115 pasien yang memiliki data rekam medis lengkap. Tujuh puluh di antaranya mengalami gangguan elektrolit serum. Jenis gangguan elektrolit serum terbanyak dialami adalah hipokalsemia (17,34\%). Dari 173 pasien diare dengan dehidrasi, 64,74\% berjenis kelamin laki-laki, 43,35\% berusia 12-35 bulan, 83,24\% mengalami muntah, $52,6 \%$ mengalami demam, 4,62\% mengalami dehidrasi berat. Penelitian ini tidak membuktikan adanya hubungan signifikan antara derajat dehidrasi terhadap gangguan elektrolit $(\mathrm{p}=0,243)$.

Kesimpulan. Prevalensi gangguan elektrolit serum pada pasien diare dengan dehidrasi pada anak adalah 40,46\%. Sari Pediatri 2018;20(1):37-42

Kata Kunci: diare, dehidrasi, gangguan elektrolit serum

\section{Prevalence of Serum Electrolyte Disorder in Children Under Five with Diarrhea and Dehydration in Dr. Sardjito Hospital on 2013-2016}

Rosyida Avicennianing Tyas, ${ }^{*}$ Wahyu Damayanti, ${ }^{* *}$ Eggi Arguni**

Background. Until now, diarrhea is still one of the world health problems, primarily in developing country. One of the complications of dehydration in diarrhea is serum electrolyte disorder.

Objective. To determine the prevalence of serum electrolyte disorder in diarrhea patients with dehydration and the patient clinical characteristics, and the relationship of dehydration level to serum electrolyte disorder.

Methods. This was a retrospective study with cross-sectional design using medical records. The differences analyzed using Chi-Square. Results. Of the total 173 patients, those met the criteria, 115 patients with complete medical records. Serum electrolyte disorder was observed in 70 patients. The major serum electrolyte disorder noted were hypocalcemia (17,34\%). Of 173 diarrhea patients with dehydration, $64,74 \%$ were males, $43,35 \%$ were aged between 12 to 35 months, $83,24 \%$ had vomiting, 52,6\% had a fever, $4,62 \%$ had severe dehydration. This study didn't show any relationship of dehydration level to serum electrolyte profile $(\mathrm{p}=0,243)$.

Conclusion. The prevalence of serum electrolyte disorder is 40,46\%. Sari Pediatri 2018;20(1):37-42

Keywords: diarrhea, dehydration, serum electrolyte disorder

Alamat korespondensi: Rosyida Avicennianing Tyas. Fakultas Kedokteran Kesehatan Masyarakat dan Keperawatan Universitas Gadjah Mada/RSUP Dr. Sardjito, Yogyakarta. Email: rosyidaceni@gmail.com 


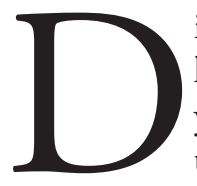
iare adalah buang air besar 3 kali atau lebih per hari dengan konsistensi tinja yang melembek atau cair. ${ }^{1}$ Penyebab utama diare adalah infeksi rotavirus. ${ }^{2}$ Angka morbiditas dan mortalitas anak tinggi akibat diare. ${ }^{3}$ Kasus diare akut di dunia diperkirakan 1,7 milyar, mengakibatkan 700.000 kematian setiap tahunnya pada anak di bawah usia 5 tahun. ${ }^{4}$ Di negara berkembang, penyakit diare merupakan penyebab dari 17,5\%-21\% kematian pada balita, setara dengan 1,5 juta kematian per tahun. Dari seluruh anak yang meninggal karena diare, $78 \%$ terjadi di Afrika dan Asia Tenggara. ${ }^{5}$

Tanda dan gejala yang termanifestasi bergantung pada patogen yang menginfeksi. Umumnya, pasien akan mengalami buang air besar cair. Muntah dan demam dapat terjadi sebelum atau selama diare berlangsung, atau bahkan tidak muncul sama sekali. Manifestasi selanjutnya bergantung pada jumlah cairan dan elektrolit yang hilang dari tubuh. ${ }^{6}$

Sebagian besar komplikasi yang terjadi pada gastroenteritis berhubungan dengan keterlambatan diagnosis dan pemberian terapi yang tidak tepat. ${ }^{7}$ Dehidrasi berlanjut menjadi gangguan elektrolit dan asidosis metabolik merupakan komplikasi tersering terjadi dan paling berbahaya. ${ }^{8}$ Penyakit diare dan dehidrasi berperan dalam 14\%-30\% kematian bayi dan balita di dunia. ${ }^{9}$ Pengukuran kadar elektrolit serum harus dilakukan saat anak mengalami dehidrasi berat atau sedang yang menunjukkan tanda gangguan elektrolit, seperti kejang, perut kembung, atau kelemahan otot. ${ }^{10}$

Berbagai jenis gangguan elektrolit yang terjadi, seperti abnormalitas kadar natrium $(\mathrm{Na})$, kalium $(\mathrm{K})$, magnesium $(\mathrm{Mg})$, klorida $(\mathrm{Cl})$ dan kalsium $(\mathrm{Ca})$ dalam serum, ${ }^{11}$ berhubungan dengan peningkatan laju mortalitas anak dengan diare. Gangguan elektrolit ini dapat tidak terdeteksi, tetapi menyebabkan peningkatan morbiditas dan mortalitas. ${ }^{12}$

Vesikari clinical severity scoring system adalah salah satu sistem skoring yang digunakan untuk menilai tingkat keparahan diare. Terdapat tujuh parameter skoring yang digunakan dalam vesikari score. Parameter ini memperhitungkan setiap gejala yang dianggap penting pada profil tampakan klinis pasien. Setiap parameter dibagi menjadi tiga distribusi keparahan. ${ }^{13}$

Penelitian ini dilakukan dengan tujuan untuk mengetahui prevalensi gangguan elektrolit serum pada pasien diare dengan dehidrasi usia kurang dari 5 tahun di RSUP Dr. Sardjito tahun 2013 - 2016 serta karakteristik klinis pasien dan untuk mengetahui hubungan antara derajat dehidrasi terhadap gangguan elektrolit serum.

\section{Metode}

Penelitian ini merupakan penelitian retrospektif dengan rancangan potong melintang. Data sekunder yang digunakan berupa rekam medis pasien usia kurang dari 5 tahun di RSUP Dr. Sardjito dalam periode waktu 1 Januari 2013 hingga 31 Desember 2016. Kriteria inklusi mencakup pasien yang memiliki rekam medis lengkap yang didiagnosis diare dengan dehidrasi (ICD-10 A09 dan E86) dan menjalani rawat inap atau rawat intensif di instalasi kesehatan anak di RSUP Dr. Sardjito, sedangkan pasien yang mengalami gangguan ginjal dieksklusi dari penelitian. Estimasi besar sampel yang diperlukan 151 pasien.

Data pasien dari rekam medis yang dikumpulkan meliputi nomor rekam medis, jenis kelamin, usia, berat badan, tinggi badan, frekuensi dan durasi diare, frekuensi dan durasi muntah, suhu tubuh, derajat dehidrasi, tingkat pendidikan ibu, komorbiditas, dan hasil pemeriksaan elektrolit serum $(\mathrm{Na}, \mathrm{K}, \mathrm{Ca}$, $\mathrm{Cl})$. Data yang diperoleh dimasukkan ke dalam tabel dan dianalisis secara deskriptif untuk menghitung prevalensi gangguan elektrolit serum dan melihat karakteristik dari pasien diare dengan dehidrasi. Uji normalitas dilakukan untuk melihat sebaran data. Untuk mengetahui hubungan antara gangguan elektrolit terhadap derajat dehidrasi digunakan uji $C h i$ square. Evaluasi statistik dilakukan dengan program komputer. Perbedaan bermakna secara statistik ditetapkan dengan nilai $\mathrm{p}<0,05$.

\section{Hasil}

Dari total 203 pasien yang didiagnosis diare dengan dehidrasi dan menjalani perawatan, terdapat 30 pasien yang harus dieksklusi dari penelitian. Karakteristik pasien tertera pada Tabel 1. Rerata usia 173 pasien tersebut adalah $18,78 \pm 14,54$ bulan dengan nilai tengah 14 bulan, pasien paling muda berusia 1 bulan dan paling tua 57 bulan. Jumlah pasien laki-laki lebih banyak dibandingkan perempuan [112 (64,7\%); 
$61(35,3 \%)]$. Dari 173 pasien tersebut, $83,2 \%$ di antaranya mengalami gejala muntah, sedangkan $52,6 \%$ mengalami gejala demam.

Dari 173 pasien tersebut, $115(66,5 \%)$ memiliki data rekam medis lengkap. Tabel 2 menunjukkan data hasil laboratorium pemeriksaan kadar elektrolit serum yang pertama kali dilakukan pada pasien setelah didiagnosis diare dengan dehidrasi.

Di antara 115 pasien diare dengan dehidrasi yang dilakukan pemeriksaan kadar elektrolit serum, 70 pasien memiliki kadar elektrolit serum di luar batas normal. Dengan demikian, prevalensi gangguan elektrolit serum pada pasien diare dengan dehidrasi usia kurang dari 5 tahun yang menjalani rawat inap atau rawat intensif di Instalasi Kesehatan Anak RSUP Dr. Sardjito tahun 2013-2016 adalah 40,5\%.

Sebaran jenis gangguan elektrolit serum yang dialami 70 pasien tersebut tertera pada Tabel 3 .

Data yang diperoleh menunjukkan bahwa gangguan elektrolit serum terbanyak dialami oleh pasien adalah hipokalsemia, yaitu 30 (17,3\%) pasien,

Tabel 1. Karakteristik pasien diare dengan dehidrasi

\begin{tabular}{lc}
\hline Variabel & $\begin{array}{c}\text { Frekuensi }(\%) \\
\mathrm{N}=173\end{array}$ \\
\hline Jenis kelamin & $112(64,7)$ \\
Laki-laki & $61(35,3)$ \\
Perempuan & \\
Usia (bulan) & $71(41)$ \\
$<12$ & $75(43,4)$ \\
$12-35$ & $27(15,6)$ \\
$36-59$ & \\
Gejala muntah & $144(83,2)$ \\
Ya & $29(16,8)$ \\
Tidak & \\
Demam $\left(>37,5^{\circ} \mathrm{C}\right)$ & $91(52,6)$ \\
Ya & $82(47,4)$ \\
Tidak & \\
Derajat Dehidrasi & $165(95,4)$ \\
Tidak berat & $8(4,6)$ \\
Berat &
\end{tabular}

Tabel 2. Hasil pemeriksaan kadar elektrolit serum pasien

\begin{tabular}{lc}
\hline & Nilai tengah \\
\hline Natrium & $136(104,2-158)$ \\
Kalium & $4,04(1,70-6,73)$ \\
Kalsium (83 pasien) & $2,21(1,43-2,58)$ \\
Klorida (114 pasien) & $104(69-133)$ \\
\hline
\end{tabular}

diikuti hiponatremia dan hipokalemia masing-masing $23(13,3 \%)$ pasien.

Terdapat $88,2 \%$ pasien yang memiliki komorbiditas penyakit lain dengan malnutrisi adalah komorbidi-

Tabel 3. Jenis gangguan elektrolit serum pasien

\begin{tabular}{lc}
\hline $\begin{array}{l}\text { Jenis gangguan elektrolit } \\
\text { serum }\end{array}$ & $\begin{array}{c}\text { Frekuensi }(\%) \\
\mathrm{N}=70\end{array}$ \\
\hline Hipernatremia & $8(11,6)$ \\
Hiponatremia & $23(32,9)$ \\
Hiperkalemia & $12(17,1)$ \\
Hipokalemia & $23(32,9)$ \\
Hiperkalsemia & $3(4,3)$ \\
Hipokalsemia & $29(42,9)$ \\
Hiperkloremia & $11(15,7)$ \\
Hipokloremia & $8(11,4)$ \\
\hline
\end{tabular}

Tabel 4. Karakteristik pasien yang mengalami gangguan elektrolit serum

\begin{tabular}{lc}
\hline Variabel & Frekuensi (\%) \\
& $\mathrm{N}=70$ \\
\hline Jenis kelamin & \\
Laki-laki & $47(67,1)$ \\
Perempuan & $23(32,9)$ \\
Usia (bulan) & \\
$<12$ & $37(52,9)$ \\
$12-35$ & $19(27,1)$ \\
$36-59$ & $14(20)$ \\
Status gizi & \\
$<-2$ SD & $22(31,4)$ \\
$\geq-2$ SD & $48(68,6)$ \\
Gejala muntah & \\
Ya & $58(82,9)$ \\
Tidak & $12(17,1)$ \\
Demam $\left(>37,5^{\circ} \mathrm{C}\right)$ & \\
Ya & $41(58,6)$ \\
Tidak & $29(41,4)$ \\
Skor Vesikari & \\
Ringan $(<7)$ & $1(1,4)$ \\
Sedang $(7-10)$ & $11(15,7)$ \\
Berat $(>10)$ & $58(82,9)$ \\
Derajat dehidrasi & \\
Tidak berat & $64(91,4)$ \\
Berat & $6(8,6)$ \\
Tingkat pendidikan ibu & \\
Rendah & \\
Tinggi & $23(32,9)$ \\
\hline
\end{tabular}


tas yang paling banyak dialami. Karakteristik lainnya tertera pada Tabel 4.

Di antara 173 pasien, 4 pasien meninggal selama rawatan rumah sakit. Seluruhnya mengalami gangguan elektrolit dengan jenis gangguan elektrolit yang bervariasi. Seluruh pasien berusia kurang dari 1 tahun mengalami sepsis dan memiliki komorbiditas penyakit lain.

Di antara 108 pasien dengan dehidrasi tidak berat, 64 memiliki kadar elektrolit serum yang tidak normal. Sebaliknya, di antara 7 pasien dengan dehidrasi berat, 6 memiliki kadar elektrolit serum tidak normal.

Analisis menggunakan Fisher Exact Test menunjukkan perbedaan yang tidak signifikan (nilai $p>0,05$ ) pada perbandingan proporsi pasien yang mengalami gangguan elektrolit serum dengan pasien yang memiliki kadar elektrolit serum normal terhadap derajat dehidrasinya, berat atau tidak berat.

\section{Pembahasan}

Total $70(40,46 \%)$ dari 173 pasien diare dengan dehidrasi yang mengalami gangguan elektrolit serum. Dehidrasi dan gangguan keseimbangan elektrolit adalah komplikasi umum diare akut pada anak. Hal tersebut terjadi karena anak memiliki perbedaan fisiologis mayor dengan orang dewasa, seperti total luas permukaan tubuh, struktur ginjal dan sistem endokrin yang belum matur, serta level metabolik anak lebih tinggi. ${ }^{4}$

Penelitian Chambuso dkk, ${ }^{14}$ di Mwanza, Tanzania, melaporkan bahwa prevalensi defisiensi elektrolit pada pasien diare usia kurang dari 5 tahun adalah 54,5\%. ${ }^{14}$ Sementara di Nigeria, gangguan elektrolit dan asam basa ditemukan $165(89,2 \%)$ anak dari 185 pasien. ${ }^{4}$

Ditemukan 30 (17,3\%) pasien hipokalsemia yang merupakan gangguan elektrolit terbanyak. Sembilan puluh sembilan persen kalsium total tubuh tersimpan dalam tulang dan homeostasis kalsium diregulasi oleh hormon paratiroid, kalsitonin, dan vitamin D. Kalsium penting untuk banyak fungsi tubuh, termasuk metabolisme tulang, aktivitas neuromuskular, konduksi elektrik jantung dan otot polos, koagulasi, serta fungsi eksokrin dan endokrin. Kurang dari $1 \%$ dari total kalsium berada di cairan ekstraselular. Konsentrasi kalsium serum normal dijaga pada rentang 2,15-2,5 mmol/L. Hampir 50\% kalsium serum diikat oleh protein, terutama albumin sehingga kondisi hipoalbuminemia akan menyebabkan berkurangnya konsentrasi kalsium serum kurang. ${ }^{15}$

Kalsium serum terionisasi tidak terikat dan merupakan bentuk aktif biologis. Konsentrasi normal kalsium terionisasi adalah 1,12-1,3 mmol/L. Konsentrasi kalsium terionisasi biasanya tidak sesuai dengan konsentrasi kalsium total, tetapi merupakan indikator yang lebih terpercaya untuk melihat status fungsional konsentrasi kalsium serum. Terutama pada pasien dengan penyakit kritis karena pasien ini biasanya mengalami hipoalbuminemia atau imbalansi asam basa, yang dapat memengaruhi pengikatan protein. ${ }^{15}$

Devrajani $\mathrm{dkk}^{16}$ melakukan penelitian di Pakistan pada pasien dengan gastroenteritis akut usia lebih dari 12 tahun. Devrajani melaporkan 94\% pasien mengalami hipokalsemia, sedangkan $6 \%$ memiliki kadar kalsium serum normal. Hasil tersebut juga sesuai dengan penelitian Bovee-Oudenhoven $\mathrm{dkk}^{17}$ yang melaporkan Devrajani pasien yang mengalami diare infeksius (traveler's diarrhea) bisa membaik dengan konsumsi susu tinggi kalsium. Hasil penelitian ini berbeda dengan penelitian yang dilakukan di Pakistan. Pada penelitian tersebut, hiperkloremia adalah abnormalitas elektrolit yang paling banyak dialami $(53,8 \%)$, diikuti hiperkalemia $(26,9 \%)$, dan hipernatremia $(17,3 \%)^{12}$. Namun, penelitian ini hanya mengukur kadar natrium, kalium dan klorida, sedangkan kadar kalsium tidak diperiksa.

Data menunjukkan bahwa $64,7 \%$ pasien diare dengan dehidrasi berjenis kelamin laki-laki. Hal tersebut sesuai dengan karakteristik pasien pada beberapa penelitian yang berhubungan dengan dehidrasi akibat diare. Dari total 185 pasien diare akut dengan dehidrasi usia kurang dari 5 tahun pada penelitian Okposio $\mathrm{dkk}^{4}$ di Nigeria, $57,8 \%$ berjenis kelamin laki-laki. Selain itu, pada penelitian lain, dari total 63 pasien usia kurang dari 5 tahun dengan dehidrasi berat akibat diare akut, $34(54 \%)$ pasien di antaranya adalah laki-laki dan 29 (46\%) lainnya adalah perempuan. ${ }^{18}$

Distribusi usia pasien menunjukkan bahwa $41 \%$ pasien berusia kurang dari 12 bulan, 43,4\% pasien berusia 12-35 bulan, sedangkan 15,6\% berusia 36-59 bulan. Menurut Koletzko dan Osterrieder ${ }^{6}$ semakin muda seorang anak, semakin berisiko kehilangan cairan dan elektrolit yang dapat menyebabkan terjadinya dehidrasi.

Hasil penelitian menunjukkan bahwa 52,6\% pasien diare dengan dehidrasi mengalami demam 
dengan suhu tubuh diatas $37,5^{\circ} \mathrm{C}$, sedangkan $47,4 \%$ lainnya tidak mengalami demam. Penelitian yang dilakukan pada 185 anak yang mengalami diare akut dengan dehidrasi menunjukkan bahwa 109 (58,9\%) anak di antaranya mengalami demam. ${ }^{4}$

Non inflammatory diare bersifat cair tanpa darah ataupun mukus dan biasanya tidak disertai dengan demam. Diare ini sebagian besar disebabkan oleh virus, khususnya rotavirus, dan sering melibatkan usus halus tanpa adanya kerusakan mukosa. Berbeda dengan inflammatory diare yang menyebabkan diare berdarah disertai sel darah putih, diare ini melibatkan usus besar dan biasanya disertai dengan demam, muntah, serta nyeri abdomen. ${ }^{19}$ Demam biasanya juga tidak muncul pada pasien yang mengalami diare non infeksi. Gejala demam terjadi karena adanya proses peradangan atau akibat dari dehidrasi. ${ }^{3}$

Jumlah pasien yang mengalami gejala demam dan tidak mengalami gejala demam tidak berbeda jauh. Hal tersebut menunjukkan bahwa jumlah pasien yang mengalami inflammatory diare dan diare non infeksi serta pasien yang mengalami non-inflammatory diare memiliki perbandingan yang setara dalam penelitian ini. Namun, hasil ini juga bisa dipengaruhi aspek lain, seperti gejala demam yang belum muncul atau bahkan sudah hilang saat pasien didiagnosis diare. Selain itu, juga bisa disebabkan demam dengan suhu tubuh yang tidak terlalu tinggi sehingga tidak terdeteksi saat pemeriksaan.

Skor Vesikari dianalisis untuk melihat tingkat keparahan diare yang dialami oleh pasien, skor keparahan di atas 10 poin dianggap 'severe', skor antara 7 hingga 10 'moderate', dan skor kurang dari 7 'mild'. ${ }^{13}$ Data berupa frekuensi dan durasi diare, frekuensi dan durasi muntah, suhu tubuh maksimum, keparahan dehidrasi serta modalitas terapi dikumpulkan untuk menilai skor Vesikari pasien. Menurut Shim dkk ${ }^{20}$ pasien diare infeksi yang disebabkan patogen bakterial memiliki skor Vesikari yang lebih tinggi secara bermakna dibanding pasien dengan diare viral dan non-spesifik. Diare bakterial yang merusak usus besar biasanya ditandai dengan frekuensi dan durasi diare yang lebih tinggi, sedangkan diare yang disebabkan oleh virus cenderung memiliki manifestasi muntah yang lebih dominan. Terdapat 58 anak atau $82,9 \%$ pasien yang mengalami gangguan elektrolit serum memiliki skor Vesikari lebih dari sama dengan 10 atau dikategorikan sebagai diare parah.

Dari 173 pasien yang memiliki data rekam medis lengkap, hanya 8 orang yang terdiagnosis mengalami dehidrasi berat. Hal tersebut bisa terjadi karena pencatatan rekam medis yang kurang baik. Selain itu, pasien juga bisa datang dengan dehidrasi yang tidak berat, tetapi kondisinya memburuk dalam perawatan di rumah sakit, sedangkan pencatatan derajat dehidrasinya hanya dilihat pada diagnosis awal pasien.

Dehidrasi diklasifikasikan menjadi berat jika volume cairan yang hilang lebih dari 10\% cairan tubuh total. Kadar elektrolit serum dan keseimbangan asam/basa biasanya normal pada bayi dan anak yang mengalami dehidrasi ringan. Pemeriksaan laboratorium umumnya hanya dilakukan pada anak yang mengalami dehidrasi berat. ${ }^{9}$ Hal ini tidak sepenuhnya diterapkan pada tatalaksana pasien diare di RSUP Dr. Sardjito. Pemeriksaan kadar elektrolit serum dilakukan pada lebih dari 100 orang pasien, walaupun hanya 8 orang yang didiagnosis dehidrasi berat. Ketidaksesuaian antara jumlah pasien yang mengalami diare parah dan dehidrasi berat menunjukkan bahwa keparahan diare tidak hanya dilihat dari derajat dehidrasi yang dialami pasien. Namun, terdapat faktor lain yang memengaruhi, seperti frekuensi dan durasi dari gejala demam dan muntah.

Malnutrisi adalah masalah besar global yang memiliki hubungan saling memperburuk keadaan dengan diare hingga menyebabkan tingginya morbiditas dan mortalitas anak. Anak dengan malnutrisi mengalami diare yang lebih parah dan lebih lama. Prevalensi diare 5-7 kali lebih besar pada anak malnutrisi. ${ }^{21}$ Studi epidemiologi di beberapa negara menunjukkan bahwa gizi yang buruk pada anak meningkatkan risiko terjadinya komplikasi pada kasus gastroenteritis, seperti gangguan elektrolit dan perawatan rumah sakit yang lebih lama. ${ }^{8}$ Bilal $\mathrm{dkk}^{22}$ melaporkan gangguan elektrolit pada $87,5 \%$ pasien yang mengalami diare dan malnutrisi. Malnutrisi meningkatkan frekuensi dan durasi diare sehingga waktu penyembuhan dua kali lebih lama. Diare terus menjadi masalah serius pada anak dan bisa menjadi fatal jika disertai dengan malnutrisi. Malnutrisi secara langsung memengaruhi angka kematian dan memiliki peran yang besar dalam meningkatkan beban penyakit, terutama di negara berkembang. Data menunjukkan bahwa dari 70 pasien yang mengalami gangguan elektrolit serum, 22 pasien $(31,4 \%)$ di antaranya memiliki komorbiditas malnutrisi. 
Rosyida Avicennianing Tyas dkk: Prevalensi gangguan elektrolit serum pada pasien diare dengan dehidrasi usia kurang dari 5 tahun

\section{Kesimpulan}

Prevalensi gangguan elektrolit serum pada pasien diare dengan dehidrasi usia kurang dari 5 tahun yang menjalani rawat inap atau rawat intensif di RSUP Dr. Sardjito tahun 2013-2016 adalah 40,5\%, dengan jenis gangguan elektrolit serum terbanyak dialami adalah hipokalsemia. Secara statistik, penelitian ini tidak dapat mebuktikan hubungan antara derajat dehidrasi terhadap gangguan elektrolit serum pasien diare dengan dehidrasi.

\section{Daftar pustaka}

1. World Health Organization. 2013. Diakses pada 22 Maret 2017. Didapat dari: http://www.who.int/mediacentre/factsheets/ fs330/en/.

2. Prasetyo D, Iesje MS, Yudith SE, Yati S. Association between severe dehydration in rotavirus diarrhea and exclusive breastfeeding among infants at Dr. Hasan Sadikin General Hospital, Bandung, Indonesia. J Trop Med 2015;2015:1-4.

3. Juffrie M, Soenarto SSY, Oswari H, Arief S, Rosalina I, Mulyani NS. Buku ajar gastroenterologi-hepatologi. Jilid 1. Jakarta: Badan Penerbit IDAI;2012.

4. Okposio M, Onyiriuka A, Abhulimhen-Iyoha B. Point-ofadmission serum electrolyte profile of children less than five years old with dehydration due to acute diarrhoea. Trop Med Health 2015;43:247-52.

5. World Health Organization,. WHO recommendations on the management of diarrhoea and pneumonia in hivinfected infants and children. Geneva: World Health Organization, Departments of Child and Adolescent Health and Development (CAH) and HIV/AIDS; 2010.

6. Koletzko $S$, Osterrieder $S$. acute infectious diarrhea in children. Deutsches Ärzteblatt International 2009;106:539-48.

7. Kliegman R, Richard EB, Waldo EN, penyunting.. Nelson Textbook of Pediatrics. Edisi 20. Philadelphia, PA: Elsevier; 2016.

8. Elliott E. Acute gastroenteritis in children. BMJ 2007;334:3540.

9. Powers KS. Dehydration: isonatremic, hyponatremic, and hypernatremic recognition and management. Pediatr Rev 2015;36:274-85.
10. Canavan A, Arant Jr.B.S. Diagnosis and management of dehydration in children. Am Fam Phys 2009;80:692-6.

11. Das SK, Afroze F, Ahmed T, Faruque ASG, Sarker SA, Huq $S$, dkk. Extreme hypernatremic dehydration due to potential sodium intoxication: consequences and management for an infant with diarrhea at an urban intensive care unit in Bangladesh: A Case Report. J Med Case Reports 2015;9:124.

12. Ahmad MS, Abdul W, Ahmad M, Mahboob N, Mehmood R. Prevalence of electrolyte disorders among cases of diarrhea with severe dehydration and correlation of electrolyte levels with age of the patients. J Coll Phys Surg Pak 2016;26:394-8.

13. Lewis K. Vesikari clinical severity scoring system manual 2011:1-50. Diakses pada 23 Januari 2017. Didapat dari: https://www.path.org/publications/files/VAD_vesikari_scoring_ manual.pdf.

14. Chambuso S, Okamo B, Silago V, Mushi MF, Kamugisha E. Prevalence and outcomes of electrolyte deficiency in children under five with diarrhea in Mwanza, Tanzania. JYI 2017;33:46-8.

15. Bartel B, Gau E. Fluid and Electrolyte Management. Jones \& Bartlett Learning 2010;7:1-25.

16. Devrajani BR, Shah SZA, Shaikh S, Shaikh S, Essa S. Hypocalcemia in acute gastroenteritis (a case- control study at department of internal medicine). World Appl Sci J 2009;7:777-80.

17. Bovee-Oudenhoven IMJ, Lettink-Wissink MLG, Doesburg WV, Witteman BJM, Meer RVD. Diarrhea caused by enterotoxigenic escherichia coli infection. Am Gastroenterol Assoc 2003;125:469-76.

18. Onyiriuka A, Iheagwara E. Serum electrolyte profiles of underfive Nigerian children admitted for severe dehydration due to acute diarrhea. Niger J Health Sci 2015;15:14-7.

19. Churgay CA, Aftab Z. Gastroenteritis in Children: Part 1. Diagnosis 2012;85:1059-062.

20. Shim DH, Kim DY, Cho KY. Diagnostic value of the Vesikari scoring system for predicting the viral or bacterial pathogens in pediatric gastroenteritis. Korean J Pediatr 2016;59:126-31.

21. Memon Y, Majeed R, Ghani MH, Shaikh S. Serum Electrolytes Changes in Malnourished Children with Diarrhoea. Pak J Med Sci 2007;23:760-4.

22. Bilal A, Sadiq MA, Haider N. Frequency of Hyponatraemia and Hypokalaemia in Malnourished Children with Diarrhea 2016;66:1077-80. 